\title{
Editorial
}

\section{Religion, Education, Security}

\author{
Liam Francis Gearon $(1)$
}

Department of Education, University of Oxford, Oxford OX2 6PY, UK; liam.gearon@education.ox.ac.uk

Received: 19 April 2019; Accepted: 8 May 2019; Published: 16 May 2019

\begin{abstract}
On first glance the politicization and securitization of religion may seem remote from education. A second look reveals widespread international initiatives aimed at the uses of education precisely for political and security purposes, notably in the countering of terrorism, violent extremism and ideologies opposed to liberal democratic values. This editorial presents a critical framing on how scholars from a range of interrelated disciplines analyze the interface of religion, education and security. The purpose of this Special Issue is thus critically to engage scholars across religious studies and theology, politics and international relations, security and intelligence studies, to explore through empirical evidence and reasoned argument the role here for religion in education. The volume aims to make some ground-breaking cross-disciplinary theoretical advances and methodological innovations not simply to further debate but to provide the tools for asking new questions and opening new pathways and frameworks for exploring the critical interface of religion, education and security.
\end{abstract}

Keywords: religion; security; education; terrorism; counter-terrorism; security studies; intelligence studies; political theology

In Schmitt (2005) Political Theology, a critical historicity allowed him to claim that 'All significant concepts of the modern theory of the state are secularized theological concepts' (Schmitt 2005, p. 36). Schmitt, above all theorists, demonstrates how the political becomes 'theological'. Voegelin (1999) analysis of the 'political religions' (Maier 2004, 2007; Maier and Schafer 2007) here draws theorists to the enduring legacies of autocracy, dictatorship and totalitarianism (Arendt 2004; Casanova 1994, 2009; Friedrich and Brzezinski 1967; Popper 2011; Power 2010; Talmon 1961).

In the present, the resurgence of religion in public life has been marked by intense debates over global governance (Burleigh 2009; Davis et al. 2007; Habermas 2006, 2008; Haynes 2008, 2009; Huntington 2002; Wood et al. 2016), issues which now permeate international religious education (Davis and Miroshnikova 2017). These debates have often been framed as variant forms of political theology (De Vries and Sullivan 2006; Schussler Fiorenza et al. 2013; Scott and Cavanaugh 2011). Critically, the resurgence of religion in the public sphere has marked too by reconsiderations of secularization theory (Berger 1999; Bruce 2002; Davie et al. 2008; Habermas 2008; Habermas and Ratzinger 2007; Stark 1999; Taylor 2007).

Concurrently, across security and intelligence studies, theorists have noted a marked expansion or 'securitization' to a number of different domains (Albert and Buzan 2011; Buzan 2007; Collins 2018; Dunn Cavelty and Balzacq 2016; Taureck 2006; Wæver 1995; Huysmans 1998; also Seiple et al. 2011). Securitization theory presents a means of exposure, a frame of exposition and a method of analysis of this claimed expansion of security across five such areas of human experience: military, political, societal, economic, and environmental (Huysmans 1998; Van Munster 2016). Bagge Laustsen and Wæver (2000), even prior to 9/11, suggested adding a sixth category of religion.

On first glance the politicization and securitization of religion may seem remote from education. A second look reveals widespread international initiatives aimed at the uses of education precisely for political and security purposes, notably in the countering of terrorism, violent extremism and ideologies opposed to liberal democratic values (Ghosh et al. 2016). The European Agenda on Security 
(EAS 2015) has here increasingly drawn universities into the fray, while in the UK specifically, the Counter Terrorism and Security Act 2015 has given public bodies, including educational institutions, legislative responsibilities for maintaining and enhancing security and preventing terrorism, and the ideologies which allow terrorism to flourish. The editor's conceptualisations of the 'counter-terrorist classroom' (Gearon 2013) and the 'counter-terrorist campus' (Gearon 2017a, 2017b, 2017c, 2018; Gearon and Prud'homme 2018) have sparked at times vituperative debate (Jackson 2015; Lewin 2017).

The central aim of this volume is critically to engage scholars across religious studies and theology, politics and international relations, security and intelligence studies, to explore through empirical evidence and reasoned argument the role here for religion in education.

In the opening article Joseph Prud'homme's 'Security, Religion, and Political Culture: A Defense of Weak Disestablishment' provides a critical analysis of the role of religion, religion, the state and education in the United States. Drawing on a thesis advanced in Gearon and Prud'homme (2018), Prud'homme notes that many in the West have long argued against state religious establishments on the ethical grounds of the rights of freedom of conscience and personal autonomy. Prud'homme extends such analyses to explore the impact of religious disestablishment on state provision of security and preventing violent extremism in education.

Pia-Maria Niemi, Arto Kallioniemi and Ratna Ghosh's 'Religion as a Human Right and a Security Threat-Investigating Young Adults' Experiences of Religion in Finland' examines the pedagogical and wider educational implications of the emergence of religiously motivated terrorist attacks and xenophobia across Europe from a Scandinavian perspective. Finely juxtaposing the tensions between rights and threats, or security and liberty, their empirical data highlights findings which open the field for further comparative and international study.

Pia-Maria Niemi, Saija Benjamin, Arniika Kuusisto and Liam Gearon's 'How and Why Education Counters Ideological Extremism in Finland' also examines the Finnish context, examining how the intensification of radical and extremist thinking has become an international cause of concern and the fear related to terrorism has increased worldwide, and, while mindful of such international contexts, shows what such impacts have meant in practical, pedagogical terms for Finnish Education.

The renowned scholar on religion and global politics, Jeffrey Haynes examines religion, education and security from precisely such a worldwide perspective by assessing the relationship between the United Nations Alliance of Civilisations and educational and policy notions of global citizenship.

Robyn Sneath's article is 'Fancy Schools for Fancy People: Risks and Rewards in Fieldwork Research Among the Low German Mennonites of Canada and Mexico'. Detailing her research on modern-day Mennonites she provides an historical note on the 1920s exodus of 8000 Mennonites from the Canadian prairie provinces of Manitoba and Saskatchewan to Mexico and Paraguay, as a matter of particular as well as wider theoretical importance to the special issue's theme. Providing a methodological addendum on historical and ethnographic approaches to the study of religion, education and security, Sneath reminds us that history can teach us much about these matters of acute contemporary relevance.

Isaac Calvert's 'Sanctifying Security: Jewish Approaches to Religious Education in Jerusalem' demonstrates precisely how the historical and contemporary significance of religion and security in education still have momentous geopolitical charge. Drawing on his groundbreaking ethnographic fieldwork in Jerusalem, Calvert treats in situ of the critical pedagogical meeting place of politics and theology in twenty-first century Jewish education.

Liam Gearon's 'The Educational Sociology and Political Theology of Disenchantment: From the Secularization to the Securitization of the Sacred' draws significantly on two theorists who have helped shape sociological and political theological thinking-Weber $(1946,2015)$ and Carl Schmitt (2005) - Gearon provides an outline theoretical synthesis of educational sociological and political theology, through the concept of 'disenchantment' to afford insights on critical current debates around secularization and securitization in education. 
Terence Lovat's 'Securing Security in Education: The Role of Public Theology and a Case Study in Global Jihadism' argues for the theoretical and methodological tool of public theology as a vital adjunct to contemporary education's addressing of security issues in light of current world events with indisputable religious and arguably quasi-theological foundations.

The volume here initiates some ground-breaking cross-disciplinary theoretical advances and methodological innovations not simply to further debate but to provide the tools for asking new questions and opening new pathways and frameworks for exploring the critical interface of religion, education and security.

Conflicts of Interest: The author declares no conflict of interest.

\section{References}

Albert, Mathias, and Barry Buzan. 2011. Securitization, sectors and functional differentiation. Security Dialogue 42: 413-25. [CrossRef]

Arendt, Hannah. 2004. The Origins of Totalitarianism. New York: Schocken Books.

Berger, Peter, ed. 1999. The Desecularization of the World: Resurgent Religion and World Politics. Grand Rapids: Eerdmans.

Bruce, Steve. 2002. God Is Dead. Oxford: Blackwell.

Burleigh, Michael. 2009. Sacred Causes: Religion and Politics from the European Dictators to Al Qaeda. London: Harper. Buzan, Barry. 2007. People, States, and Fear, 2nd ed. Boulder: Lynne Rienner.

Casanova, Jose. 1994. Public Religions in the Modern World. Chicago: Chicago University Press.

Casanova, Jose. 2009. The secular and secularism. Social Research 76: 1049-66.

Collins, Alan, ed. 2018. Contemporary Security Studies. Oxford: Oxford University Press.

Davie, Grace, Peter Berger, and Effie Fokas. 2008. Religious America, Secular Europe? Aldershot: Ashgate.

Davis, Derek, and Elena Miroshnikova, eds. 2017. The Routledge International Handbook of Religious Education. London and New York: Routledge.

Davis, Creston, John Milbank, and Slavoj Zizek. 2007. Theology and the Political: The New Debate. Durham: Duke University Press.

De Vries, Hent, and Lawrence E. Sullivan, eds. 2006. Political Theologies: Public Religions in a Post-Secular World. New York: Fordham.

Dunn Cavelty, Myriam, and Thierry Balzacq, eds. 2016. The Routledge Handbook of Security Studies. London: Routledge.

EAS. 2015. European Agenda on Security. Brussels: European Commission, Available online: https://ec.europa.eu/ home-affairs/what-we-do/policies/european-agenda-security_en (accessed on 17 April 2019).

Friedrich, Carl Joachim, and Zbigniew K. Brzezinski. 1967. Totalitarian Dictatorship and Autocracy. New York: Praeger.

Gearon, Liam. 2013. The Counter Terrorist Classroom: Religion, Education, and Security. Religious Education 108: 129-47. [CrossRef]

Gearon, Liam. 2017a. Secularisation and the Securitisation of the Sacred: A Response to Lewin's Framing of the Gearon-Jackson Debate. British Journal of Educational Studies 65: 469-80. [CrossRef]

Gearon, Liam. 2017b. Paradigm Shift in Religious Education: A Reply to Jackson, or Why Religious Education Goes to War. Journal of Beliefs and Values 39: 358-78. [CrossRef]

Gearon, Liam. 2017c. The Counter-Terrorist Campus: Securitisation Theory and University Securitisation-Three Models. Transformation in Higher Education 2. Available online: https://thejournal.org.za/index.php/thejournal/ article/view/13/51 (accessed on 21 December 2018). [CrossRef]

Gearon, Liam. 2018. Terrorism and Counter-Terrorism Policy and Research in UK Universities (1997-2017): An Analytic-Structural Review of the Literature and Related Sources. Policy Reviews in Higher Education 2: 32-60. [CrossRef]

Gearon, Liam, and Joseph Prud'homme. 2018. State Religious Education and the State of the Religious Life. Eugene: Wipf and Stock.

Ghosh, Ratna, Ashley Manuel, W. Y. Alice Chan, Maihemuti Dilimulati, and Mehdi Babaei. 2016. Education and Security: A Global Literature Review on the Role of Education in Countering Violent Religious Extremism. London: 
Tony Blair Institute for Global Change, Available online: https://institute.global/sites/default/files/inline-files/ IGC_Education\%20and\%20Security.pdf (accessed on 17 April 2019).

Habermas, Jurgen. 2006. Religion in the public sphere. European Journal of Philosophy 14: 1-25. [CrossRef]

Habermas, Jurgen. 2008. Notes on post secular society. New Perspectives Quarterly 25: 17-29. [CrossRef]

Habermas, Jurgen, and Joseph Ratzinger. 2007. The Dialectics of Secularization: On Reason and Religion. San Francisco: Ignatius Press.

Haynes, Jeffrey, ed. 2008. The Handbook of Religion and Politics. London: Routledge.

Haynes, Jeffrey, ed. 2009. Religion and Politics. London: Routledge.

Huntington, Samuel. 2002. The Clash of Civilizations. New York: Simon \& Schuster.

Huysmans, Jeff. 1998. Revisiting Copenhagen: Or, on the creative development of a security studies agenda in Europe. European Journal of International Relations 4: 479-505. [CrossRef]

Jackson, Robert. 2015. The politicization and securitization of religious education? A rejoinder. British Journal of Educational Studies 63: 345-66. [CrossRef]

Laustsen, Carsten Bagge, and Ole Wæver. 2000. In defence of religion: Sacred referent objects for securitization. Millennium: Journal for International Studies 29: 705-39. [CrossRef]

Lewin, David. 2017. Who's afraid of secularization? Reframing the debate between Gearon and Jackson. British Journal of Educational Studies 64: 445-61. [CrossRef]

Maier, Hans, ed. 2004. Totalitarianism and Political Religions. London: Routledge, vol. I.

Maier, Hans, ed. 2007. Totalitarianism and Political Religions. London: Routledge, vol. III.

Maier, Hans, and Michael Schafer Schafer, eds. 2007. Totalitarianism and Political Religions. London: Routledge, vol. II.

Popper, Karl. 2011. The Open Society and Its Enemies. London: Routledge.

Power, Samantha. 2010. A Problem from Hell: America in the Age of Genocide. London: Flamingo.

Schussler Fiorenza, Francis, Klaus Tanner, and Michael Welker, eds. 2013. Political Theology: Contemporary Challenges and Future Directions. Louisville: Westminster John Knox Press.

Schmitt, Carl. 2005. Political Theology: Four Chapters on the Concept of Sovereignty. Chicago: Chicago University Press.

Scott, Pete, and William T. Cavanaugh, eds. 2011. The Blackwell Companion of Political Theology. Oxford: Wiley-Blackwell.

Seiple, Chris, Dennis R. Hooper, and Pauletta Otis, eds. 2011. Routledge Handbook of Religion and Security: Theory and Practice. London and New York: Routledge.

Stark, Rodney. 1999. Secularization, RIP. Sociology of Religion 60: 249-73. [CrossRef]

Talmon, Jacob L. 1961. The Origins of Totalitarian Democracy. London: Mercury Books.

Taureck, Rita. 2006. Securitization Theory and Securitization Studies. Journal of International Relations and Development 9: 53-61. [CrossRef]

Taylor, Charles. 2007. A Secular Age. Cambridge: Harvard University Press.

Van Munster, Rens. 2016. Securitization. Oxford Bibliographies. Available online: http://oxfordindex.oup.com/view/ 10.1093/obo/9780199743292-0091 (accessed on 21 December 2018).

Voegelin, Eric. 1999. The Collected Works of Eric Voegelin, Volume 5: Modernity without Restraint: The Political Religions, The New Science of Politics and Science, Politics and Gnosticism. Edited by Manfred Henningsen. Columbia: University of Missouri.

Weber, Max. 1946. Science as a Vocation. In From Max Weber: Essays in Sociology. New York: Oxford University Press, pp. 129-56.

Weber, Max. 2015. Max Weber's 'Science as a Vocation'. Edited by Peter Lassman, Irving Velody and Herminio Martins. London: Routledge.

Wæver, Ole. 1995. Securitization and DeSecuritization. In On Security. Edited by R. D. Lipschuts. New York: Columbia University Press, pp. 46-86.

Wood, Linda, David Partridge, and Hiroko Kawanami, eds. 2016. Religions in the Modern World. London: Routledge.

(C) 2019 by the author. Licensee MDPI, Basel, Switzerland. This article is an open access article distributed under the terms and conditions of the Creative Commons Attribution (CC BY) license (http://creativecommons.org/licenses/by/4.0/). 